\title{
"THE COLORIMETRIC ESTIMATION OF ALPHA-AMINO NITROGEN IN TISSUE FLUIDS
}

\author{
BY \\ H. M. RUBINSTEIN* AND J. D. PRYCE \\ From the Departments of Chemical Pathology and Haematology, \\ Postgraduate Medical School of London
}

(RECEIVED FOR PUBLICATION FEBRUARY 8, 1958)

Various authors have reported methods for the colorimetric estimation of alpha-amino nitrogen with ninhydrin (Moore and Stein, 1948, 1954 ; Smith and Agiza, 1951 ; Troll and Cannan, 1953 ; Yemm and Cocking, 1955 ; Kalant, 1956 ; Rosen, 1957). Only Kalant has applied this method to the direct measurement of alpha-amino nitrogen in biological fluids; he reported on the determination of total alpha-amino nitrogen in dog plasma.

This paper describes a colorimetric ninhydrin method for amino-acid determination, based on that of Troll and Cannan. It differs in using disodium ethylenediamine tetra-acetic acid (E.D.T.A.) instead of pyridine to enhance colour development. This improves reproducibility by eliminating trace metal interferences, and yields lower blanks than the pyridine reagent. In addition, we use a separate buffer to maintain the $p \mathrm{H}$ optimal at 5.1. For the first time a technique has been evolved for applying the colorimetric ninhydrin procedure to biological fluids generally, and, in particular, it has been successfully applied to urine.

The optimum conditions for $p \mathrm{H}$ and concentration of cyanide, ninhydrin, and other reagents have been studied, and the optimal time for heating has been established. With the exception of the E.D.T.A. concentration, all the factors are moderately critical.

\section{A : Method for Simple Solutions of Amino-acids}

Buffer-—Add $300 \mathrm{ml}$. of $2 \mathrm{M}$-sodium acetate (164 g./1. anhydrous salt) to $700 \mathrm{ml}$. of $2 \mathrm{M}$-acetic acid (120 ml. glacial acetic acid/1.). Add approximately $5 \mathrm{~g}$. of disodium ethylenediamine tetra-acetate and exactly $240 \mathrm{mg}$. of potassium cyanide. Preserve with chloroform. This solution is stable indefinitely.

Phenol Reagent.-Dissolve $400 \mathrm{~g}$. of phenol in $100 \mathrm{ml}$. of absolute ethanol by heating. Cool and add approximately $5 \mathrm{~g}$. of " permutit" (Decalso F). Stir well for 10 minutes and filter. Even moderate colour due to oxidation of the phenol does not interfere with subsequent determinations.

Ninhydrin.-Dissolve $6 \mathrm{~g}$. of ninhydrin in $100 \mathrm{ml}$. of absolute ethanol by vigorous stirring. Add approximately $2 \mathrm{~g}$. of "permutit" and stir for 10 minutes. Filter and store in a brown bottle. The solution is a pale yellow-green. If the solution is contaminated by protein or amino-acid the colour will change.

Stock Standard.-Any full-colour amino-acid is suitable (Table I). Monosodium glutamate (mol. wt.

TABLE I

COLOUR VALUES OF AMINO-ACIDS AND RELATED COMPOUNDS RELATIVE TO GLUTAMIC ACID ON A MOLAR BASIS

\begin{tabular}{|c|c|c|}
\hline Full (97-103\%) & High & Low \\
\hline $\begin{array}{l}\text { Glycine } \\
\text { Alanine } \\
\text { Leucine } \\
\text { Isoleucine } \\
\text { Valine } \\
\text { Serine } \\
\text { Histidine } \\
\text { Citrulline } \\
\text { Threonine } \\
\text { Artinine } \\
\text { Methionine } \\
\text { Aspartic acid } \\
\text { Asparagine } \\
\text { Glutamine } \\
\text { Cysteic acid }\end{array}$ & $\begin{array}{l}\text { Lysine } 110 \% \\
\text { Ornithine } 110 \% \\
\text { Cystine } 121 \%\end{array}$ & $\begin{array}{l}\text { Phenylalanine } 94 \% \\
\text { Tyrosine } 88 \% \\
\text { Tryptophan } 78 \% \\
\text { Taurine } 29 \% \\
\text { Beta alanine } 8 \% \\
\text { Ammonia nitrogen } 46 \% \\
\text { Ethanolamine } 16 \% \\
\text { Ethylenodiamine } 16 \% \\
\text { Methylamine } 8 \% \\
\text { Ethylamine } 3 \% \\
\text { Urea } 0.09 \% \\
\text { Creatinine } 0.26 \% \\
\text { Uric acid } 0.00 \\
\text { Hippuric acid } 0.07 \% \text { or les }\end{array}$ \\
\hline
\end{tabular}

187.14) has been used in this laboratory. Dissolve $935.7 \mathrm{mg}$. in distilled water and make up to $100 \mathrm{ml}$. This solution is $0.05 \mathrm{M}$. Preserve with chloroform.

Working Standard.-Dilute stock standard 1 in 100 with distilled water. One millilitre of the working standard contains $7.0 \mu \mathrm{g}$. alpha-amino nitrogen.

Procedure.-Add $0.5 \mathrm{ml}$. of the unknown solution (containing not more than $3.5 \mu \mathrm{g}$. of alpha-amino nitrogen) to a $6 \times \frac{3}{4}$ in. test-tube. For the blank use $0.5 \mathrm{ml}$. ammonia-free distilled water, and for the standard take $0.5 \mathrm{ml}$. of the working standard $(3.5 \mu \mathrm{g}$. of alpha-amino nitrogen). Add $0.5 \mathrm{ml}$. of buffer solution to each tube. Add $5 \mathrm{ml}$. of phenol reagent and shake until clear. Add $0.5 \mathrm{ml}$. of ninhydrin solution and shake again. Place the tubes in an actively boiling water bath for four to five minutes. It is unnecessary to stopper the tubes. Remove and cool in 
water for at least 10 minutes. Shake the tubes vigorously and equally. After shaking, the blank solution takes on a pale yellow colour, and the test solutions take on the typical purple colour. The colour fades slowly and proportionately for several hours. Allow the tubes to stand for at least 10 minutes after shaking, and read the optical density at $570 \mathrm{~m} \mu$ or with a yellow filter (Ilford 626). When read against water, the optical density of the blank is always below 0.05 .

The standard deviation of 100 consecutive duplicate determinations was $\pm 2.10 \%$. In Table $I$ are listed the relative colour values of the common amino-acids and several other compounds. Proline, hydroxyproline, and cysteine have not been included because they do not give purple colours with ninhydrin (Moore and Stein, 1948).

\section{B : Method for Plasma}

Kalant (1956) found that ethanol, trichloro-acetic acid, and sulphosalicylic acid were unsatisfactory as protein-precipitating agents, but that tungstic acid was suitable. Acetone has been tested as a precipitant, but it is unsatisfactory because of the low solubility in acetone of many amino-acids. Picric acid is a satisfactory precipitant, but a considerable amount of extra labour is involved, since the excess picric acid must be removed (Stein and Moore, 1954). Tungstic acid was selected for this study. It is not ideal because it leaves a slight residual turbidity, which necessitates that the blank and standard also be treated with the protein precipitant.

Heparinized plasma was used. Serum is, of course, unsatisfactory owing to the considerable proteolysis which occurs on clotting. Separated plasma is stable indefinitely if frozen.

Protein Precipitant.-Add 1 part of $13.3 \%(\mathrm{w} / \mathrm{v})$ sodium tungstate to 9 parts of $0.11 \mathrm{~N}$-sulphuric acid (3.1 ml. of conc. sulphuric acid/1.). This mixture should be made up every few days as it rapidly becomes turbid.

Working Standard.-Dilute $4 \mathrm{ml}$. of stock standard to $100 \mathrm{ml}$. with distilled water.

Procedure-Rinse $0.3 \mathrm{ml}$. of plasma into $0.7 \mathrm{ml}$. distilled water in a centrifuge tube. Add $3 \mathrm{ml}$. of the tungstic acid reagent with shaking. Centrifuge. Decant the supernatant through a cotton-wool plug. For the blank, add $3 \mathrm{ml}$. of the tungstic acid reagent to $1 \mathrm{ml}$. of ammonia-free distilled water, and for the standard add $3 \mathrm{ml}$. of tungstic acid reagent to $1 \mathrm{ml}$. of the working standard. In each case, analyse $0.5 \mathrm{ml}$. as in section $\mathrm{A}$, reading the optical density against water. The optical density of the blank is always below 0.075 .

Calculation.-The sample analysed is equal to $300 / 8 \mu \mathrm{l}$. of plasma ; the standard analysed contains $3.5 \mu \mathrm{g}$. alpha-amino nitrogen; and $\mu \mathrm{g}$. per $100 \mu \mathrm{l}$. equals $\mathrm{mg}$. per $100 \mathrm{ml}$.

O.D.* test - O.D. blank $\times \frac{8}{3} \times 3 \cdot 5=\mathrm{mg}$. alpha-amino nitrogen $\frac{\text { O.D. standard-O.D. blank }}{3} \times \frac{8}{3} \times 5=$ per $100 \mathrm{ml}$. plasma * O.D. = optical density.
Results.-The plasma of 29 normal laboratory workers was investigated by this method. Blood was drawn three hours after a light breakfast.

Fifteen Women.-Range $3.68-5.47 \mathrm{mg} . / 100 \mathrm{ml}$,, mean $4.52 \mathrm{mg} . / 100 \mathrm{ml}$., S.D. $\pm 0.51 \mathrm{mg} . / 100 \mathrm{ml}$.

Fourteen Men.-Range $3.68-5.25 \mathrm{mg} . / 100 \mathrm{ml}$., mean $4.56 \mathrm{mg} . / 100 \mathrm{ml}$., S.D. $\pm 0.40 \mathrm{mg} . / 100 \mathrm{ml}$.

Combined Series.-Range 3.68-5.47 mg./100 ml., mean $4.54 \mathrm{mg} . / 100 \mathrm{ml}$., S.D. $\pm 0.45 \mathrm{mg} . / 100 \mathrm{ml}$.

All specimens were analysed in duplicate and the standard deviation of the difference was $\pm 3.7 \%$.

From a patient with pernicious anaemia, 24 plasma samples were analysed over a period of six weeks. All of the values obtained fell between 3.86 and $5.23 \mathrm{mg} . / 100 \mathrm{ml}$.

Recoveries of pure amino-acids added to plasma specimens on four occasions were $97 \%, 102 \%, 96 \%$, and $103 \%$.

\section{C : Method for Cerebrospinal Fluid}

The reagents are those for plasma. Rinse $0.6 \mathrm{ml}$. of cerebrospinal fluid into $0.4 \mathrm{ml}$. of distilled water in a centrifuge tube. Continue exactly as for plasma, preparing the blank and standard in the same manner.

Calculation.-The sample analysed contains $600 / 8$ $\mu 1$. cerebrospinal fluid. Hence,

$$
\begin{gathered}
\frac{\text { O.D. } * \text { test }- \text { O.D. blank }}{\text { O.D. standard }- \text { O.D. blank }} \\
\text { * O.D. }=\text { optical density. }
\end{gathered}
$$

Results.-Five fresh specimens of cerebrospinal fluid normal with respect to protein and cell content were investigated. The values were 1.08, 1.39, 1.44, 1.45 , and $1.25 \mathrm{mg} . / 100 \mathrm{ml}$.

\section{D : Method for Urine}

The principal problem in measuring urinary aminoacids by this method is completely to rid the sample of ammonia. This can be achieved by adding alkali to the urine sample, and evaporating to dryness over concentrāted sulphuric acid.

For free alpha-amino nitrogen, the reagents are as follows:

Alkali Solution.-0.05 M-potassium carbonate $(6.9 \mathrm{~g}$. $/ 1$. of the anhydrous salt).

Working Standard.-Dilute stock standard 1:1 with distilled water.

Procedure.-Rinse $0.2 \mathrm{ml}$. urine into $2 \mathrm{ml}$. 0.05 M-potassium carbonate solution in a small beaker. For the blank, substitute $0.2 \mathrm{ml}$. distilled water for the urine, and for the standard, substitute $0.2 \mathrm{ml}$. of the working standard. Place all the beakers in a large vacuum desiccator, the bottom of which contains $300-400 \mathrm{ml}$. of concentrated sulphuric acid. Evacuate the desiccator to a pressure of $20-30 \mathrm{~mm}$. Hg. Allow the solutions in the beakers to go to dryness. This takes several hours, but it is most convenient to do this step overnight. Dissolve the residue in $10 \mathrm{ml}$. distilled water. Take $0.5 \mathrm{ml}$. of each for analysis as in section A. The optical density of the blank is always below 0.05 . 
Calculation.-The sample analysed contains $10 \mu \mathrm{l}$. of urine, and the standard $3.5 \mu \mathrm{g}$. of alpha-amino nitrogen. Thus,

$$
\begin{gathered}
\frac{\text { O.D.* tost }- \text { O.D. blank }}{\text { O.D. standard-O.D. blank }} \times 10 \times 3 \cdot 5=\begin{array}{l}
\text { mg. free alpha-amino } \\
\text { nitrogen per } 100 \mathrm{ml} \text {. urine }
\end{array} \\
\text { O.D. }=\text { optical density. }
\end{gathered}
$$

Results and Discussion.-This method was applied to 24-hour urine collections from 20 normal laboratory workers. The specimens were preserved with $6 \mathrm{ml}$. each of toluene and chloroform, and stored at $4^{\circ}$ until analysed. Results are given in Table II.

TABLE II

\begin{tabular}{|c|c|c|c|}
\hline $\begin{array}{c}\text { Urinary Alpha-amino } \\
\text { Nitrogen }\end{array}$ & Range & Mean (士S.D.) & $\begin{array}{c}\text { Significance } \\
\text { of Difference } \\
\text { between } \\
\text { Male and } \\
\text { Female } \\
\text { Values }\end{array}$ \\
\hline $\begin{array}{lr}\begin{array}{l}\text { Free } \\
\text { Concentration }\end{array} & 8 * \\
\text { (mg./100 ml.) } & 12 \dagger \\
\text { combined } \\
\text { Total } & 8 \\
\text { (mg./24 hours) } & 12 \\
\text { combined } \\
\text { Mg./kg./24 hours } & 8 \\
& 12 \\
\text { combined }\end{array}$ & $\begin{array}{c}8.06-15.54 \\
6.95-17.52 \\
75.8-197 \cdot 1 \\
78.0-203.1 \\
1.39-3.44 \\
0.98-3.27 \\
-\end{array}$ & 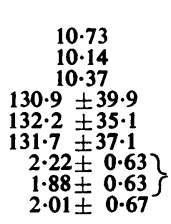 & $P=0.26$ \\
\hline $\begin{array}{lr}\text { Total } & \\
\text { Concentration } & 8 \\
\text { (mg./100 ml.) } & 12 \\
\text { combined } \\
\text { Total } & 8 \\
\text { (mg./24 hours) } & 12 \\
\text { combined } \\
\text { Mg. } / \text { kg. } / 24 \text { hours } 8 \\
\\
\text { combined }\end{array}$ & $\begin{array}{c}14 \cdot 51-29 \cdot 34 \\
14 \cdot 24-31 \cdot 60 \\
192 \cdot 0-426 \cdot 2 \\
186.4-423.0 \\
3.52-7.44 \\
2 \cdot 75-6.20 \\
\text { - }\end{array}$ & 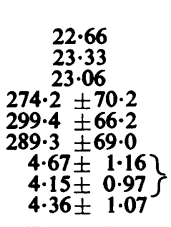 & $P=0.32$ \\
\hline $\begin{array}{lr}\begin{array}{l}\text { Bound } \\
\text { Total }\end{array} \\
\text { (mg./24 hours) } \\
\text { combined } \\
12 \\
\text { Mg./kg./24 hours } 8 \\
\\
\text { combined }\end{array}$ & $\begin{array}{r}81.8-229.1 \\
100.9-259.6 \\
1.24-4.00 \\
1.62-3.06\end{array}$ & $\left.\begin{array}{r}143.3 \pm 46.2 \\
167.2 \pm 44.2 \\
157.6 \pm 45.0 \\
2.45 \pm 0.79 \\
2.28 \pm 0.44 \\
2.35 \pm 0.60\end{array}\right\}$ & $P=0.56$ \\
\hline $\begin{array}{lr}\text { Ratio } \\
\text { Total/free } & 8 \\
\text { (mg./24 hours) } & 12 \\
& \text { combined }\end{array}$ & $\begin{array}{cc}1.50- & 2.67 \\
1.65- & 2.82 \\
- & \end{array}$ & $\left.\begin{array}{l}2 \cdot 17 \pm 0.39 \\
2 \cdot 32 \pm 0 \cdot 36 \\
2 \cdot 26 \pm 0.38\end{array}\right\}$ & $P=0.41$ \\
\hline
\end{tabular}

URINARY FREE, TOTAL, AND BOUND ALPHA-AMINO NITROGEN IN 20 NORMAL PEOPLE

The alkali solution employed decreases the anticipated colour of the standard by about $5 \%$, an effect not present when a weaker alkali solution is substituted. Using the $0.05 \mathrm{M}$-carbonate solution, up to 15 times the amount of ammonia normally present in urine may be completely removed. Since the maximum urinary ammonia may exceed the average by 10 to 12-fold, it seems advisable to use the 0.05 M-solution. Studies at various alkali concentrations have shown that standard and test solutions are proportionately affected, and the analytical results are unchanged. Recovery of pure amino-acids added to urine on five successive occasions gave results of $104 \%, 101 \%, 95 \%, 99 \%$, and $102 \%$.

The 20 specimens listed were analysed in duplicate, with a standard deviation of the difference of $\pm 2.8 \%$.
From the same patient mentioned earlier, seven 24-hour collections were made over a two-week period. The free alpha-amino nitrogen ranged from 74.6 to $99.7 \mathrm{mg}$. per 24 hours.

\section{Total Alpha-amino Nitrogen}

After acid hydrolysis, the urine ammonia level may rise over 50-fold due to decomposition of urea. Consequently, a higher alkali concentration is necessary for complete removal of ammonia by diffusion-absorption.

Alkali Solutions.-These are 0.40 M-potassium carbonate (55.2 g. $/ 1$. of the anhydrous salt), and 0.25 M-potassium carbonate $(34.6 \mathrm{~g}$./1. of the anhydrous salt).

Working Standard.-This is the same as for free alpha-amino nitrogen.

Procedure.-To $2 \mathrm{ml}$. of urine in a $6 \times \frac{1}{2}$ in. "pyrex" test-tube add $1 \mathrm{ml}$. of concentrated hydrochloric acid. Seal the tube in a gas-oxygen flame and hydrolyse in an oven at $150^{\circ}$ overnight. Allow to cool. Open the tube cautiously and remove the humin by decanting the hydrolysate through a cotton-wool plug.

Rinse $0.15 \mathrm{ml}$. of the hydrolysate into $2 \mathrm{ml}$. of $0.40 \mathrm{M}$-carbonate solution in a small beaker. At this point prepare the blank and standard by adding $0.2 \mathrm{ml}$. distilled water and $0.2 \mathrm{ml}$. working standard respectively to $2 \mathrm{ml}$. of $0.25 \mathrm{M}$-carbonate solution in individual small beakers. Proceed now exactly as listed under free alpha-amino nitrogen.

Calculation.-As $150 \mu \mathrm{l}$. of hydrolysate equals $100 \mu 1$. of the original sample, and $5 \mu \mathrm{l}$. of urine is in the final sample, therefore,

$$
\begin{gathered}
\frac{\text { O.D. } * \text { test }- \text { O.D. blank }}{\text { O.D. standard-O.D. blank }} \\
* \text { O.D. }=\text { optical density. }
\end{gathered}
$$

Results and Discussion.-The 20 normal urine specimens were also analysed for total alpha-amino nitrogen: the results are given in Table II. The standard deviation of the variation of the duplicate estimations was $\pm 3.2 \%$. The seven specimens from the patient mentioned earlier showed values between 266.0 and $303.2 \mathrm{mg}$. $/ 24$ hours.

The higher alkali concentration used for the test solution is calculated to equal the concentration employed for the blank and standard solutions after neutralization of the hydrochloric acid.

As noted for free alpha-amino nitrogen, treatment with alkali produces fading of the standard, generally from 8 to $10 \%$. For the reasons given earlier, the analytical results are unaffected, and two recoveries with pure amino-acids added to urine before hydrolysis were $98 \%$ and $99 \%$.

Hydrolysis at $150^{\circ}$ gave results about $5 \%$ higher than hydrolysis at $125^{\circ}$.

When glutamic acid and glycine were hydrolysed under the conditions above, there was a 4 to $5 \%$ loss. It was thought improbable that the various 
amino-acids in the hydrolysed test solution would behave quantitatively similarly, and there would still exist uncertainty about the actual extent of aminoacid destruction. For this reason the standard was not routinely brought through the hydrolysis procedure. Consequently it is quite possible that the values for total alpha-amino nitrogen are underestimated to the extent of a small percentage.

\section{Discussion}

The standard procedure for determining plasma alpha-amino nitrogen is the ninhydrin- $\mathrm{CO}_{2}$ method of Hamilton and Van Slyke (1943). Normal values by this technique have been published by the originators and by a number of other investigators (Woodruff and Man, 1945 ; Bonsnes, 1947 ; Brewer, Brown, Harvey, and Horwitt, 1947 ; Burt, 1953). The values given for plasma range from 3.3 to $5 \mathrm{mg}$. $/ 100 \mathrm{ml}$., with a mean of 4.1 to 4.2. The present method gives a mean and range about $10 \%$ higher than the gasometric technique. While the manometric method is probably more specific, the colorimetric procedure is far simpler and seems adequate for clinical applications.

The few figures presented here on alphaamino nitrogen in cerebrospinal fluid agree with those of Christensen, Cooper, Johnson, and Lynch (1947), who report ninhydrin- $\mathrm{CO}_{2}$ determinations on six specimens, with results ranging from 1.04 to $1.43 \mathrm{mg} . / 100 \mathrm{ml}$.

Concerning urine levels, accurate data are limited. Thompson and Abdulnabi (1950), using the ninhydrin- $\mathrm{CO}_{2}$ technique, give the average 24-hour output of free alpha-amino nitrogen as $126 \pm 67 \mathrm{mg}$. for females (11) and $101 \pm 39 \mathrm{mg}$. for males (13), with a combined mean of $113 \mathrm{mg}$./ 24 hours.

Eckhardt and Davidson (1949), by the same method, studied one case on varying protein intake, and found levels ranging from $63 \mathrm{mg}$. to $140 \mathrm{mg}$. $/ 24$ hours. On a moderate protein intake the excretion was $118 \mathrm{mg}$. $/ 24$ hours.

The gasometric method used in the two studies cited above does not estimate taurine (Van Slyke, Dillon, MacFadyen, and Hamilton, 1941). If one wishes to include this compound, which is excreted in large amounts, about $17 \mathrm{mg}$./ 24 hours must be added to the previous figures (Stein, 1953).

Stein (1953), using column separation and colorimetric ninhydrin estimation, has given figures for free urinary amino-acids on six normals. The values range from 97 to $145 \mathrm{mg}$. alpha-amino nitrogen / 24 hours, with a mean of 120 .

The present series gives a combined mean of $131.7 \pm 31.1 \mathrm{mg}$. free alpha-amino nitrogen/24 hours, with a range of 75.8 to 203.2. It must be recalled (Table I) that only about one-third of the taurine is estimated by the present method. This error is roughly cancelled out by the error due to urea (see below). In view of the difference in technique and material, and the relatively small series reported in every case, the agreement between the previous and the present data is good.

Concerning the total alpha-amino nitrogen of urine, Thompson and Abdulnabi (1950) report the 24-hour output as $321 \pm 138 \mathrm{mg}$. for females and $251 \pm 66 \mathrm{mg}$. for males, with a combined mean of $283 \mathrm{mg} . / 24$ hours. Eckhardt and Davidson (1949) report a value of $575 \mathrm{mg}$. $/ 24$ hours on their single case while on a moderate protein intake. Stein (1953) gives results on two cases as 356 and $455 \mathrm{mg}$. $/ 24$ hours respectively.

The present series gives a mean of $289.3 \pm 69$ mg. $/ 24$ hours, with a range of 186.4 to 426.2 . In the present series, unlike the results reported by Thompson and Abdulnabi (1950), no significant sex difference was found, either for free or total alpha-amino nitrogen, when the results were calculated on a weight basis.

The data in Table I show that urea, creatinine, and hippuric acid all react to a slight extent. It can readily be calculated that the interference of the last two, even when present in abnormally large amounts, is negligible. With average urinary outputs of amino-acid and urea, the positive error due to urea is about $5 \%$. If the amino-acid excretion were very low and the urea excretion very high, the error could reach $10 \%$. In the reverse case of a low urea and high aminoacid excretion, the error would fall to about $2 \%$. The error due to urea does not affect the results for total alpha-amino nitrogen, for urea is destroyed by the hydrolysis.

No attempt was made to remove urea from the sample before testing, or to correct for the actual urea content, because the principal use of a method for measuring free urinary amino-acids is in the screening for, and investigation of, cases of pathological amino-acid urea. In cases where the free amino-acid excretion is above the normal range, the error due to urea will drop to $1 \%$ or less, and may be ignored.

\section{Summary}

A simple variation of the colorimetric ninhydrin technique for estimating alpha-amino nitrogen is presented. Its application to plasma, cerebrospinal fluid, and urine is described. A series of normal values for these fluids obtained by the 
present method is given. The present technique gives approximately the same values as other methods already described.

Our grateful thanks are due to Professor E. J. King for his advice and guidance, and to Dr. I. D. P. Wootton, and Dr. C. E. Dalgleish, who provided answers for many of the problems encountered.

\section{REFERENCES}

Bonsnes, R. W. (1947). J. biol. Chem., 168, 345.

Brewer, G. E. F., Brown, W. S., Harvey, C. C., and Horwitt, M. K. (1947). Ibid., 168, 145.

Burt, R. L. (1953). Amer. J. Obstet. Gynec., 65, 304.
Christensen, H. N., Cooper, P. F., Johnson, R. D., and Lynch, E. L. (1947). J. biol. Chem., 168, 191.

Eckhardt, R. D., and Davidson, C. S. (1949). Ibid., 177, 687.

Hamilton, P. B., and Van Slyke, D. D. (1943). Ibid., 150, 231.

Kalant, H. (1956). Analyt. Chem., 28, 265.

Moore, S., and Stein, W. H. (1948). J. biol. Chem., 176, 367. (1954). Ibid., 211, 907.

Rosen, H. (1957). Arch. Biochem., 67, 10.

Smith, A. M., and Agiza, A. H. (1951). Analyst, 76, 623.

Stein, W. H. (1953). J. biol. Chem., 201, 45.

- and Moore, S. (1954). Ibid., 211, 915.

Thompson, R. C., and Abdulnabi, M. (1950). Ibid., 185, 625.

Troll, W., and Cannan, R. K. (1953). Ibid., 200, 803.

Van Slyke, D. D., Dillon, R. T., MacFadyen, D. A., and Hamilton, P. (1941). Ibid., 141, 627.

Woodruff, C. W., and Man, E. B. (1945). Ibid., 157, 93.

Yomm, E. W., and Cocking, E. C. (1955). Analyst, 80, 209. 